\title{
Growth and Instability in Wheat Production: A Region Wise Analysis of Uttar Pradesh, India
}

\author{
Harshita Tewari ${ }^{*}$, H.P. Singh ${ }^{1}$ and Usha Tripathi ${ }^{2}$ \\ ${ }^{1}$ Department of Agricultural Economics, Institute of Agricultural Sciences, \\ Banaras Hindu University, Varanasi, India \\ ${ }^{2}$ Malviya Moolya Anusheelan Kendra, Banaras Hindu University, Varanasi, India \\ *Corresponding author
}

\section{A B S T R A C T}

\begin{tabular}{|l|}
\hline Key w o r d s \\
Instability, Growth, \\
Decomposition \\
analysis, Wheat, \\
Cuddy-Della Valle \\
index.
\end{tabular}

The paper analyzes the growth and instability in terms of area, production and productivity of wheat in Uttar Pradesh. The growth was examined by compound annual growth rate and contribution of area and productivity towards output growth by decomposition analysis. The study relates to 1990-91 to 2013-14 which is further divided into five sub-periods. The area under wheat registered positive growth throughout the period in all the regions of the state. While, in case of production and productivity, the positive growth was observed except sub-period III. The productivity of wheat was found to be highest in western region whereas lowest in the Bundelkhand region. After instability analysis it was observed that there is high instability in production and productivity as compared to area under wheat. Further, the growth in wheat production is decomposed into three components viz. area effect, yield effect and interaction effect. The results of decomposition analysis revealed the dominance of yield effect in the growth of production.

\section{Introduction}

Uttar Pradesh is one of the agrarian states in the country and has emerged as the biggest contributor i.e. about 13 per cent to country's agriculture sector. Agriculture contributes about 22 per cent in the state's Gross Domestic Product (GDP), in contrast to, about 14 per cent in the country's GDP.

The state has acquired $15^{\text {th }}$ position amid top 20 states in India with 3.2 per cent compounded annual growth rate (CAGR) in agriculture and allied sector during the decadal period of 2004-05 and 2013-14 (Assocham Economic Research Bureau, AERB).
Agriculture and allied is the main source of livelihood to majority of population in Uttar Pradesh. More than 70 per cent of population is directly or indirectly depend on agriculture and allied sectors. Being a large state, Uttar Pradesh has wide variation in the soil characteristics and properties which makes it a home of variety of cereals, pulses, oilseeds and horticulture crops.

Agriculture growth and instability is the subject of major concern among the researchers and policy makers. While the need for increasing agricultural production or growth is obvious, the increase in instability 
in agricultural production is considered adverse for several reasons (Chand and Raju, 2009). A decent agricultural growth, on one hand, is a prerequisite for achieving inclusive growth, reducing poverty levels, developing the rural economy and enhancing farm incomes (Swain, 2012) while instability in production increases the vulnerability of low income household by affecting price stability (Acharya, 2001), on the other hand.

Previous studies suggested that instability in agricultural production is on rise due to several factors such as erratic rainfall pattern, low irrigation coverage, frequent droughts and other natural disaster and so on. These factors become serious due to poor capacity of the farming community to cope up with the adverse climatic conditions. Thus, the challenge with the policy maker is to increase the growth and reduce instability in agricultural production.

Wheat is one of the major cereals crops in India as well as Uttar Pradesh. Specifically, wheat accounted the highest share in gross cropped area followed by rice, bajra and maize among cereal group in the state. It plays vital role in ensuring food and economic security. At the time of independence, wheat was imported to meet the food demand of the country. The productivity of wheat in 1950-51 was reported around 6.63 quintal/ ha which was increased to 27.5 quintal/ha in 2014-15 due to different crop improvement and crop management programmes. In 2015-16, production of wheat was 96.64 million tonnes at national level whereas 28.89 million tonnes in Uttar Pradesh.

The nature and sources of growth in production and instability has been debated since Green Revolution Period. This paper makes an attempt to analyze the nature and sources of growth and instability in area, production and productivity of wheat in Uttar Pradesh with specific objectives as follows:
To study the growth and instability in area, production and productivity of wheat in Uttar Pradesh.

To examine the contribution of area and productivity towards the growth in wheat production.

\section{Materials and Methods}

Uttar Pradesh, fifth largest state of the country, is divided into four regions, namely, Eastern (28 districts), Western (30 districts), Central (10 districts) and Bundelkhand (7 districts). The whole study was carried out on the basis of regional division of the state.

The study utilizes the time series data of area, production and productivity of wheat for the period 1990-91 to 2014-15. The whole period i.e. from $1990-91$ to $2014-15$ is divided into five sub periods viz. I period (1990-91 to 1994-95), II period (1995-96 to 1999-2000), III (2000-01 to 2004-05), IV period (2005-06 to 2009-10) and V period (2010-11 to 201415). Each period consist of five years to capture the effect of drought and dry spell during the period of 25 years. The data was collected from Uttar Pradesh Sankhiyiki Patrika, Directorate of Economics and Statistics, Government of India and Agricultural Statistics at a Glance. The growth of area, production and productivity was calculated with help of following formula:

$\boldsymbol{Y}=\boldsymbol{a} \cdot \boldsymbol{b}^{t}$

Where,

$\mathrm{Y}$ is area/production/ productivity of wheat;

a is constant;

$\mathrm{b}$ is the coefficient;

$\mathrm{t}$ is the time variable

While estimating the compound annual growth rate, it was found that the production 
and productivity of wheat was quite low in 2014-15 as compared to previous year due to adverse climatic conditions i.e. untimely rainfall and hailstorm during harvest.

Therefore, the data of agriculture year 201415 was excluded from the analysis.

Further, instability in area, production and productivity of wheat was measured by Cuddy-Della Valle instability index (\%) with the help of following formula:

Instability Index $=C V \sqrt{\left(1-\overline{R^{2}}\right)}$

Where,

$\mathrm{CV}$ is the coefficient of variation in per cent;

$\mathrm{R}^{2}$ is the adjusted coefficient of determination from a time trend regression.

To measure the contribution of area and productivity towards the growth of production, decomposition analysis was used. The formula used:

$P=A_{o}\left(Y_{n}-Y_{o}\right)+Y_{o}\left(A_{n}-A_{o}\right)+\Delta A \Delta Y$

Where,

$\mathrm{P}$ is change in production

$\mathrm{Y}_{\mathrm{O}}$ is yield in base year

$\mathrm{Y}_{\mathrm{n}}$ is yield in current year

$A_{o}$ is area in base year

$A_{n}$ is area in current year

$\Delta \mathrm{A}$ is change in area

$\Delta \mathrm{Y}$ is change in yield

In the above equation, first component denotes the yield effect (productivity contribution), second component denotes the area effect (area contribution) and last component is the interaction effect of area and productivity.

\section{Results and Discussion}

The region-wise growth, instability and factors contributing towards the growth in wheat production in Uttar Pradesh under five sub-period are discussed under the following heads:

Growth and trend in area, production and productivity of wheat

The trend in area, production and productivity of wheat is presented in figure 1-3. The figure shows the increasing trend in area under wheat in all the regions viz. eastern, western, central and Bundelkhand. The production and productivity of wheat in all the region shows increasing trend over the period from 1990-91 to 2013-14 except 2005-06.

The decrease in productivity and production in 2014-15 as compared to the previous year is due to adverse climatic conditions during the harvesting season. The productivity of wheat in western region was found to be highest followed by central, eastern and Bundelkhand region. The continued period of poor rainfall recorded in Bundelkhand was during 2004-10, when below average and erratic rain was reported in most part of the region in all the years (Gupta et al., 2014) results in lowest wheat productivity in Bundelkhand region.

Further, the compound annual growth rates of area, production and productivity of wheat production for five sub- periods are shown in table 1. The table suggests that the area, production and productivity of wheat in all the four regions show increasing growth rate at 1 per cent level of significance during the period 1990-91 to 2013-14. During this period, the compound annual growth in production is 2.3 per cent and in productivity is 1.4 per cent of wheat in Uttar Pradesh. The positive growth in area, production and 
productivity of wheat can be seen in subperiods I, II and IV. During the sub-period III (2000-01 to 2004-05), the production and productivity of wheat shows negative growth rate i.e. -1.6 per cent and -2.2 per cent, respectively while area under wheat shows positive $(0.5 \%)$ growth rate in eastern Uttar Pradesh. Similar growth pattern can be seen in western Uttar Pradesh and Uttar Pradesh, as a whole.

In central Uttar Pradesh, area under wheat and its production was increased with the rate of 1.4 and 1.6 per cent whereas the productivity of wheat was decreased at 0.08 per cent rate during 2000-01 and 2004-05. The production and productivity of wheat during 2000-01 and 2004-05 had shown 0.2 and 1.2 per cent compound annual growth rate, respectively whereas area under wheat had shown negative growth of 0.8 per cent in Bundelkhand region of Uttar Pradesh.

The exceptionally high growth in production and productivity was observed during the IV sub-period (2005-06 to 2009-10) in most of the regions of Uttar Pradesh. In 2005-06, production of wheat was reported to be reduced of $10-15 \%$ due to increase in 4.6 centigrade temperature (Ground Report India,
2011). This decrease in production may lead to high growth in production

\section{Instability analysis}

The results of instability index (Cuddy-Della Valle index) are furnished in table 2. The table shows that the instability is low in case of area under wheat as compared to production and productivity in all the regions and the state, as a whole. The stability in area under wheat cultivation implies that wheat crop hold a significant portion in cropping pattern of the state. The instability in production and productivity was found to be high in sub-period III in most of the regions of Uttar Pradesh. The high instability in III sub-period can be supported by the results of growth analysis where negative growth was observed in that sub-period.

In Bundelkhand region of Uttar Pradesh, high instability was observed in wheat productivity (11.14\%) and production (13.73\%) during the study period which implies the high risk in the area. Whereas, lowest instability in production and productivity was observed in western region which is quite obvious as this is the prosperous part of the state in terms of agriculture.

Fig.1 Region-wise area of wheat in Uttar Pradesh over the period (1990-91 to 2014-15)

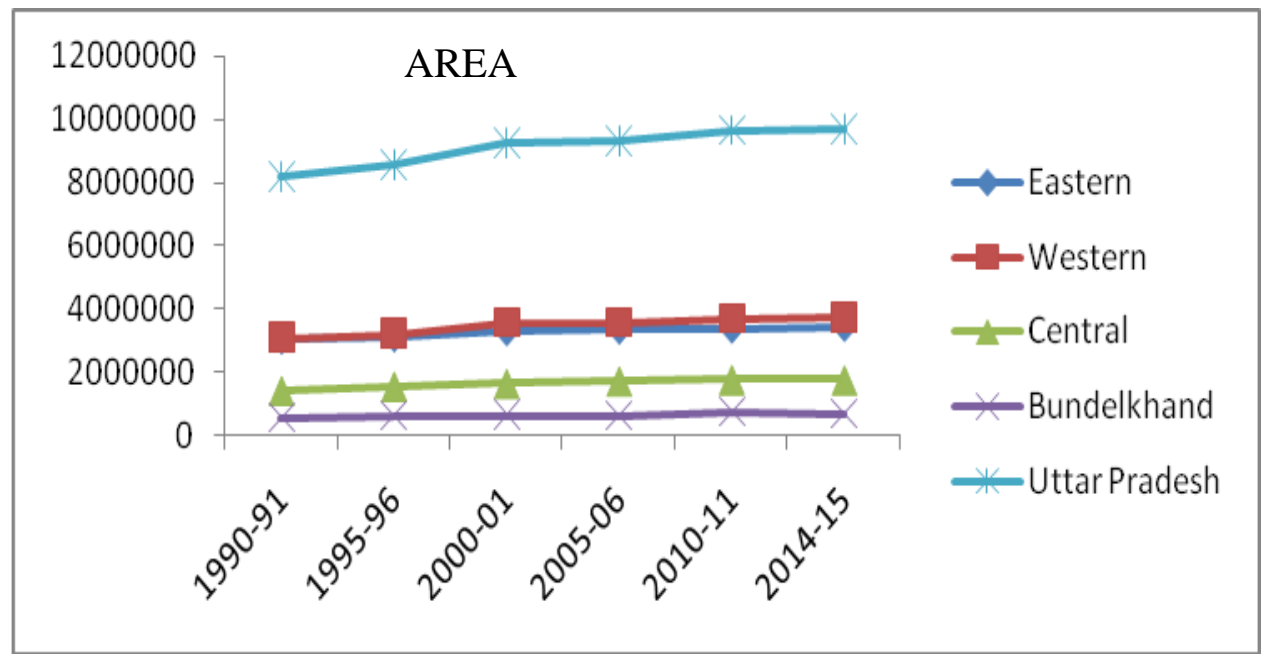


Fig.2 Region-wise production of wheat in Uttar Pradesh over the period (1990-91 to 2014-15)

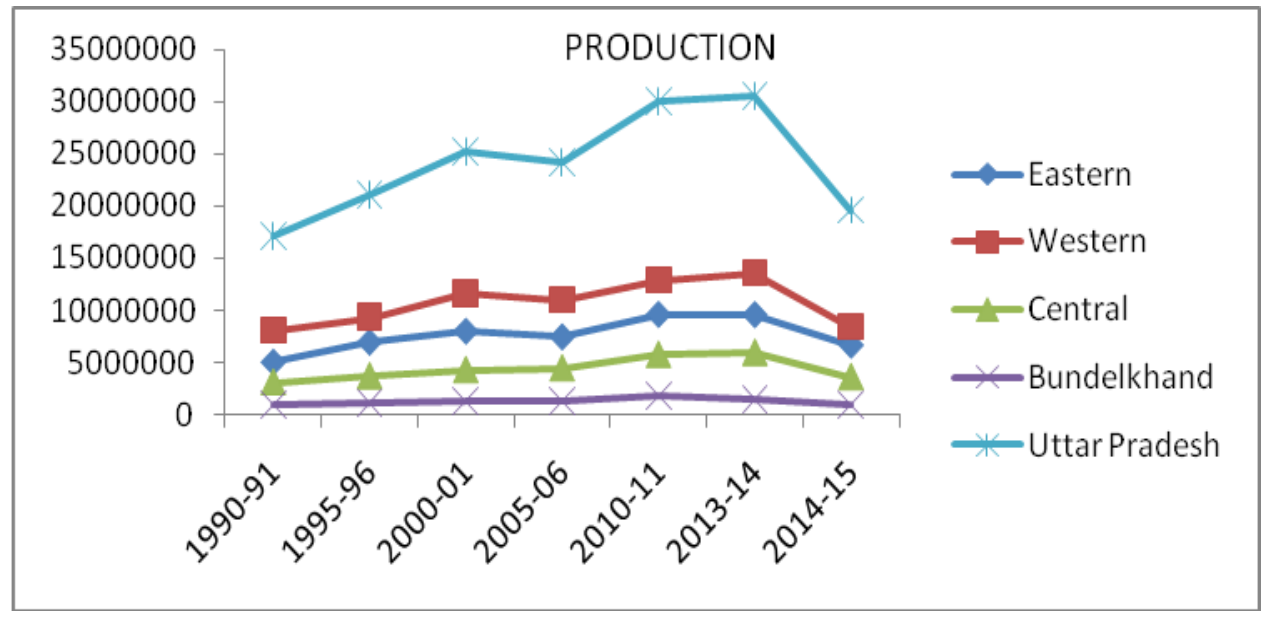

Fig.3 Region-wise productivity of wheat in Uttar Pradesh over the period (1990-91 to 2014-15)

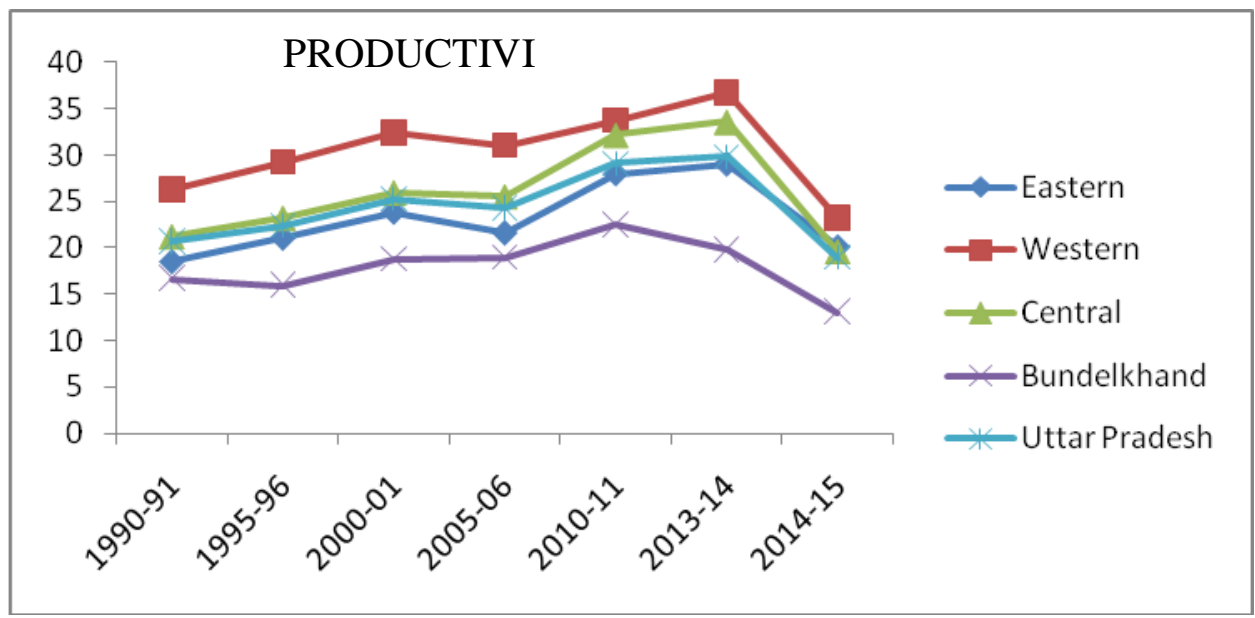

Fig.4 Contribution of yield and area towards output growth

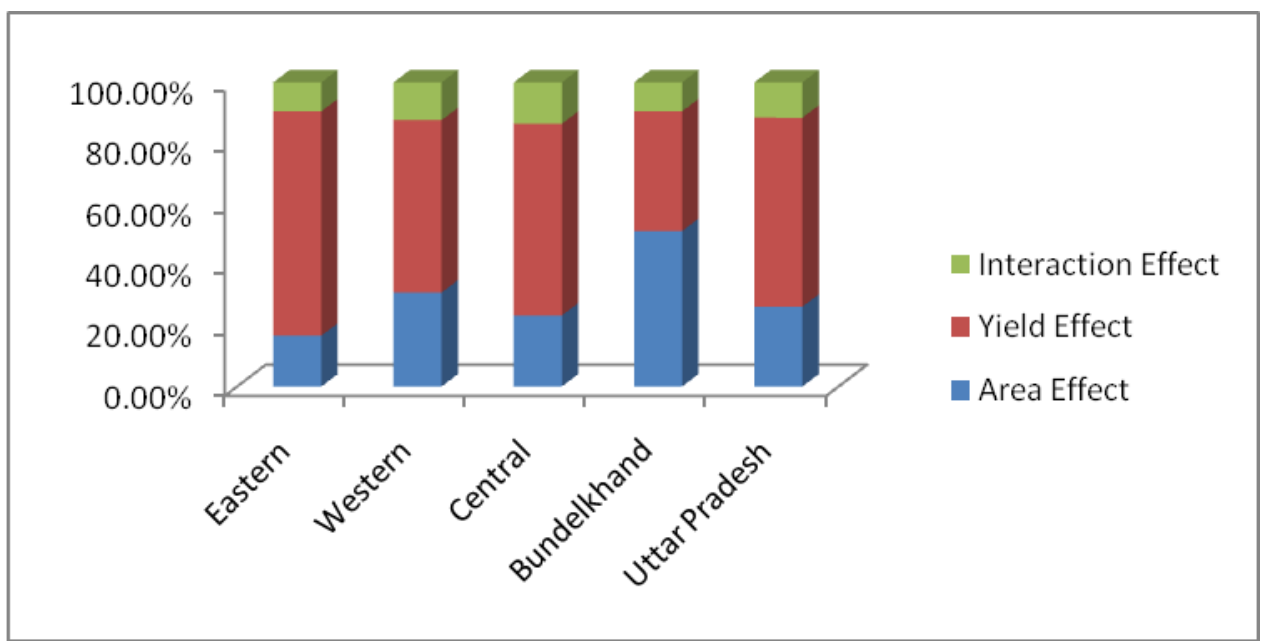


Table.1 Compound annual growth rates of area, production and productivity of wheat in Uttar Pradesh

\begin{tabular}{|c|c|c|c|c|c|c|c|}
\hline Region & Particulars & $\begin{array}{l}\text { Overall Period } \\
(1990-91 \text { to } \\
2013-14)\end{array}$ & $\begin{array}{l}\text { I } \\
(1990-91 \\
\text { to } \\
1994-95)\end{array}$ & $\begin{array}{l}\text { II } \\
(1995-96 \\
\text { to } \\
1999-00)\end{array}$ & $\begin{array}{l}\text { III } \\
(2000-01 \\
\text { to } \\
2004-05)\end{array}$ & $\begin{array}{l}\text { IV } \\
(2005-06 \\
\text { to } \\
2009-10)\end{array}$ & $\begin{array}{l}\mathbf{V} \\
(2010-11 \\
\text { to } \\
2013-14)\end{array}$ \\
\hline \multirow{3}{*}{$\begin{array}{l}\text { Eastern } \\
\text { U.P. }\end{array}$} & Area & $0.6 * * *$ & 0.3 & $1.3 * * *$ & $0.5^{*}$ & $0.7 * *$ & $0.5^{*}$ \\
\hline & Production & $2.6 * * *$ & $3.9 *$ & 2.9 & -1.6 & $4.4 *$ & -0.1 \\
\hline & Productivity & $1.6 * * *$ & $4.1 * *$ & 2.0 & -2.2 & 3.9 & 1.1 \\
\hline \multirow{3}{*}{$\begin{array}{l}\text { Western } \\
\text { U.P. }\end{array}$} & Area & $0.8 * * *$ & $2.4 * *$ & $2.2 * *$ & 0.3 & $0.9 * *$ & 0.4 \\
\hline & Production & $1.9 * * *$ & $4.7 * * *$ & $4.4 * *$ & -1.9 & $2.9 * *$ & 1.2 \\
\hline & Productivity & $1.2 * * *$ & 2.3 & $2.4^{*}$ & -1.9 & 1.6 & 2.5 \\
\hline \multirow{3}{*}{$\begin{array}{l}\text { Central } \\
\text { U.P. }\end{array}$} & Area & $0.9 * * *$ & $2.8 * * *$ & 0.7 & $1.4 * *$ & $1.2 * *$ & -0.6 \\
\hline & Production & $2.7 * * *$ & $4.8^{* *}$ & 2.9 & 1.6 & $4.4 * *$ & 0.6 \\
\hline & Productivity & $1.8 * * *$ & 1.7 & 2.6 & -0.08 & 1.3 & 1.2 \\
\hline \multirow{3}{*}{$\begin{array}{l}\text { Bundel- } \\
\text { khand }\end{array}$} & Area & $0.8 * * *$ & 1.0 & $2.7 *$ & -0.8 & $4.8^{*}$ & -0.6 \\
\hline & Production & $2.2 * * *$ & $4.6^{* *}$ & $3.2 * *$ & 0.2 & 9.6 & -6.2 \\
\hline & Productivity & $1.1 * * *$ & $3.0 * *$ & $4.3^{*}$ & 1.2 & 5.0 & -3.9 \\
\hline \multirow{3}{*}{$\begin{array}{l}\text { Uttar } \\
\text { Pradesh }\end{array}$} & Area & $0.7 * * *$ & $1.6 * * *$ & $1.7 * * *$ & 0.5 & $1.2 * *$ & 0.2 \\
\hline & Production & $2.3 * * *$ & $4.5^{* *}$ & $3.8^{*}$ & -1.1 & $4.0 * *$ & 0.3 \\
\hline & Productivity & $1.4 * * *$ & $2.7 *$ & 3.3 & -0.9 & $3.2 *$ & 0.6 \\
\hline
\end{tabular}

$*, * *, * * *$ denotes 10 per cent, 5 per cent and 1 per cent level of significance, respectively.

Table. 2 Instability in area, production and productivity of wheat in Uttar Pradesh

\begin{tabular}{|l|l|l|l|l|l|l|l|}
\hline Region & & I & II & III & IV & V & Overall \\
\hline \multirow{4}{*}{ Eastern } & Area & 0.60 & 0.39 & 0.67 & 0.43 & 0.39 & 1.54 \\
\cline { 2 - 8 } & Production & 4.92 & 5.34 & 6.61 & 5.73 & 0.62 & 7.19 \\
\cline { 2 - 8 } & Productivity & 4.76 & 7.04 & 6.37 & 5.48 & 1.94 & 7.33 \\
\hline \multirow{4}{*}{ Western } & Area & 2.24 & 0.91 & 1.70 & 0.83 & 0.73 & 2.15 \\
\cline { 2 - 8 } & Production & 2.14 & 3.17 & 3.82 & 2.89 & 2.23 & 4.87 \\
\cline { 2 - 8 } & Productivity & 4.10 & 3.14 & 2.84 & 2.98 & 3.28 & 4.44 \\
\hline \multirow{4}{*}{ Bundelkhandral } & Area & 0.74 & 1.09 & 1.02 & 0.87 & 0.91 & 2.42 \\
\cline { 2 - 8 } & Production & 6.49 & 6.71 & 4.72 & 4.22 & 1.83 & 4.67 \\
\cline { 2 - 8 } & Productivity & 5.78 & 5.44 & 3.25 & 4.53 & 1.25 & 5.06 \\
\cline { 2 - 8 } & Area & 2.16 & 2.95 & 3.03 & 6.69 & 3.51 & 4.94 \\
\cline { 2 - 8 } & Production & 3.52 & 6.11 & 9.62 & 20.32 & 8.25 & 13.73 \\
\hline \multirow{3}{*}{\begin{tabular}{l} 
Pradesh \\
\cline { 2 - 8 }
\end{tabular}} & Productivity & 2.18 & 8.70 & 7.14 & 15.64 & 9.65 & 11.14 \\
\cline { 2 - 8 } & Area & 0.82 & 0.36 & 1.05 & 0.74 & 0.45 & 1.54 \\
\cline { 2 - 8 } & Production & 3.18 & 4.56 & 4.63 & 3.81 & 1.07 & 5.12 \\
\hline
\end{tabular}


Table.3 Region-wise decomposition of output growth in wheat in Uttar Pradesh

\begin{tabular}{|c|c|c|c|c|c|c|}
\hline Particulars & $\begin{array}{l}\text { Overall } \\
\text { Period(1990- } \\
91 \text { to 2013-14) }\end{array}$ & $\begin{array}{l}\mathbf{I} \\
(1990-91 \text { to } \\
1994-95)\end{array}$ & $\begin{array}{l}\text { II } \\
(1995-96 \text { to } \\
1999-00)\end{array}$ & $\begin{array}{l}\text { III } \\
(2000-01 \text { to } \\
2004-05)\end{array}$ & $\begin{array}{l}\text { IV } \\
(2005-06 \text { to } \\
2009-10)\end{array}$ & $\begin{array}{l}\mathbf{V} \\
(2010-11 \text { to } \\
2013-14)\end{array}$ \\
\hline \multicolumn{7}{|c|}{ 1. $\quad$ Eastern Uttar Pradesh } \\
\hline Area Effect & $16.71 \%$ & $6.97 \%$ & $21.85 \%$ & $-13.36 \%$ & $13.64 \%$ & $24.53 \%$ \\
\hline Yield Effect & $73.75 \%$ & $91.57 \%$ & $74.17 \%$ & $111.75 \%$ & $84.08 \%$ & $74.56 \%$ \\
\hline Interaction Effect & $9.54 \%$ & $1.46 \%$ & $0.61 \%$ & $1.61 \%$ & $2.28 \%$ & $0.91 \%$ \\
\hline \multicolumn{7}{|c|}{ 2. Western Uttar Pradesh } \\
\hline Area Effect & $30.89 \%$ & $34.68 \%$ & $37.52 \%$ & $-8.85 \%$ & $43.57 \%$ & $15.48 \%$ \\
\hline Yield Effect & $56.68 \%$ & $60.50 \%$ & $57.54 \%$ & $108.04 \%$ & $54.54 \%$ & $83.15 \%$ \\
\hline Interaction Effect & $12.42 \%$ & $4.82 \%$ & $4.94 \%$ & $0.80 \%$ & $1.89 \%$ & $1.38 \%$ \\
\hline \multicolumn{7}{|c|}{ 3. Central Uttar Pradesh } \\
\hline Area Effect & $23.36 \%$ & $42.48 \%$ & $15.70 \%$ & $157.23 \%$ & $24.63 \%$ & $-60.81 \%$ \\
\hline Yield Effect & $63.02 \%$ & $51.77 \%$ & $81.69 \%$ & $-54.36 \%$ & $72.12 \%$ & $163.48 \%$ \\
\hline Interaction Effect & $13.62 \%$ & $5.75 \%$ & $2.61 \%$ & $-2.87 \%$ & $3.25 \%$ & $-2.67 \%$ \\
\hline \multicolumn{7}{|c|}{ 4. $\quad$ Bundelkhand Region } \\
\hline Area Effect & $51.12 \%$ & $29.68 \%$ & $21.23 \%$ & $-163.82 \%$ & $58.79 \%$ & $18.69 \%$ \\
\hline Yield Effect & $39.34 \%$ & $67.03 \%$ & $69.55 \%$ & $275.37 \%$ & $41.21 \%$ & $83.55 \%$ \\
\hline Interaction Effect & $9.54 \%$ & $3.28 \%$ & $9.22 \%$ & $-11.56 \%$ & $7.95 \%$ & $2.24 \%$ \\
\hline \multicolumn{7}{|c|}{ 5. Uttar Pradesh } \\
\hline Area Effect & $26.22 \%$ & $27.40 \%$ & $23.46 \%$ & $-41.10 \%$ & $26.89 \%$ & $18.85 \%$ \\
\hline Yield Effect & $62.17 \%$ & $68.54 \%$ & $71.69 \%$ & $139.08 \%$ & $69.98 \%$ & $80.69 \%$ \\
\hline Interaction Effect & $19.78 \%$ & $4.05 \%$ & $4.84 \%$ & $2.02 \%$ & $3.13 \%$ & $0.44 \%$ \\
\hline
\end{tabular}

\section{Decomposition analysis}

The whole decomposition analysis was divided into five sub-periods similar to growth analysis discussed above. The wheat production showed the positive growth during 1990-91 to 2013-14 in all four regions of Uttar Pradesh and the state, as a whole. But it was observed that production growth was negative in sub-period III and V in some regions of the state. Thus, this growth in wheat production was decomposed into three factors viz. area effect, yield effect and interaction effect. Table 3 shows the contribution of area, productivity and their interaction to the change in production over the years.

\section{Area effect}

Area effect was positive in all the sub-periods except in sub-period III in all the regions and the state, as a whole. At state level, area effect explained only 26.22 per cent of output growth during 1990-91 to 2013-14. Among five subperiods, negative effect $(-41.1 \%)$ of wheat area was observed in III sub-period whereas, positive effect varies from 18 to 28 per cent in I, II IV and $\mathrm{V}$ sub-period. In overall period, the area effect was found to be minimum in eastern region explaining 16.71 per cent of output growth. Exceptionally high area effect was observed in Bundelkhand region with 51.12 per cent of output growth.

The result revealed that growth in wheat production in Bundelkhand region is mainly due to increase in area which is supported by the low average wheat yield i.e. $19.76 \mathrm{qtl} /$ ha (estimated from secondary data) in the region. The table shows that the area effect explained 30.89 per cent and 23.36 per cent of output growth in Western and Central Uttar Pradesh, respectively.

\section{Yield effect}

In growth decomposition, the major portion of output growth was explained by yield effect in most of the regions and the state, as a whole in sub-periods I, II, IV and V. In sub-period III, the 
yield effect in Central region was found to be negative due to adverse climate condition during that period. It is quite obvious that the adverse climate affect the production which in turn reflects in yield. Table 3 shows that the contribution of yield to output growth has increased from sub-period I to $\mathrm{V}$ which is the result of advancement in package of practices especially high yield varieties.

\section{Interaction effect}

The interaction effect means the effect of change in area and yield together towards increase in production of wheat. It is evident from the table 2 that the interaction effect varies from 9 per cent to 20 per cent during 1990-91 to 2013-14. Thus, it can be concluded that the interaction of area and yield has a very little effect on the change in wheat production during this period.

The dominance of yield effect in increasing wheat production or output growth during 1990-91 to 2013-14 can be seen in figure 4. The area effect as compared to yield effect is high in Bundelkhand region only.

The area, production and productivity have shown the positive growth during 1990-91 to 2013-14. The negative growth in production and productivity in different regions was observed during III sub-period which is due to adverse climatic condition. Similar pattern was observed in case of instability. The instability in production and productivity was high during sub-period III in most of the regions. The instability in area under wheat was found to be low as compared to production and productivity which implies wheat is one of the major crops in the state and holds a significant place in cropping pattern of each region. Further, decomposition analysis shows the dominance of yield effect towards the change/ growth in wheat production in most of the regions of Uttar Pradesh. The whole study suggests the need to increase the productivity of the crop by applying improved package of practices especially improved crop varieties.

\section{References}

Chand, Ramesh, and S.S. Raju. 2009. Instability in Indian Agriculture during Different Phases of Technology and Policy. Indian Journal of Agricultural Economics 64 (2): 283-288.

Majumdar, K., and Basu, P. 2005. Growth Decomposition of Food grains Output in West Bengal: A District level Study. Indian Journal of Agricultural Economics, 60(2): 220-234.

Mishra, V.N., 1971, "Growth of Crop Output in Gujarat: A Component Analysis", Anvesak,1(1):1-15.

Narain, Dharm 1977. "Growth of Productivity in Indian Agriculture", Indian Journal of Agricultural Economics, 32 (1): 20-32.

Oladele, T.A., and Kenamara, D.M. 2015. Trends in Production and Export of Wheat in India.

International Research Journal of Agricultural Economics and Statistics, 6(1): 189-192.

Pattnaik, I., and Shah, A. 2015. Trends and Decomposition of Agricultural Growth and Crop Output in Gujarat: Recent Evidences. Indian Journal of Agricultural Economics, 70(2): 182-197.

Singh, R.K.P., and Kumar, P.R. 1998. Growth and instability in production of principal food grain crops: a case of backward economy. Bangladesh Journal of Agricultural Economics, XXI (1-2): 1-20.

Swain, M., 2012. Sources of Growth and Instability in Agricultural Production in Western Odisha, India. Asian Journal of Agriculture and Development, 11(2): 5170.

\section{How to cite this article:}

Harshita Tewari, H.P. Singh and Usha Tripathi. 2017. Growth and Instability in Wheat Production: A Region Wise Analysis of Uttar Pradesh. Int.J.Curr.Microbiol.App.Sci. 6(9): 2537-2544. doi: https://doi.org/10.20546/ijcmas.2017.609.312 